\title{
MENINGKATKAN HASIL BELAJAR MENGGUNAKAN MEDIA LAGU ANAK DALAM PEMBELAJARAN IPA SEKOLAH DASAR
}

\author{
Gingga Prananda ${ }^{1}$, Riyadi Saputra ${ }^{2}$, Zuhar Ricky ${ }^{3}$ \\ ${ }^{1}$ PGSD,Universitas Dharmas Indonesia ${ }^{2}$ PBI, Universitas \\ Dharmas Indonesia ${ }^{3}$ PENJASKESREK, Universitas Dharmas Indonesia \\ 1,ginggaprananda@undhari.ac.id,
}

Received: Nov 10, $2020 \quad$ Revised: Nov 13, $2020 \quad$ Accepted: Nov 16, 2020

\begin{abstract}
Abstrak
Tujuan penelitian ini adalah menggunakan media lagu anak pada siswa kelas $\mathrm{V}$ SDN 43 Sungai Sapih Padang dalam meningkatkan hasil belajar pada mata pelajaran IPA. Jenis penelitian yang digunakan adalah Penelitian Tindakan Kelas (PTK) dengan menggunakan metode kualitatif dan kuantitatif. Objek penelitian ini adalah 22 siswa kelas V. Penelitian dilakukan dalam II siklus, dan proses penelitian meliputi perencanaan, pelaksanaan, observasi dan refleksi. Hasil penelitian menunjukan bahwa $87,5 \%$ pada RPP siklus I, dan 96\% pada siklus II, 79,65 pada aspek guru pada siklus I, 95,8\% pada siklus II, dan $76,6 \%$ pada siswa siklus I. Siklus II $84,7 \%$. Kesimpulan dari penelitian ini adalah penggunaan media lagu anak dapat meningkatkan hasil belajar siswa pada mata pelajaran IPA SDN 43 Sungai Sapih Padang.
\end{abstract}

\section{Kata Kunci: Hasil Belajar, Pembelajaran IPA, Lagu Anak}

\begin{abstract}
The purpose of this study is the use of children's songs as media at Fifth Grade of SDN 43 Sungai Sapih Padang to improve learning science outcomes. Type of research used was Classroom Action Research (CAR) through qualitative and quantitative methods. Then, the objects of this research were 22 students. The research was conducted in two cycles, and the research process that included planning, implementing, observing and reflecting. The results shows that $87.5 \%$ in the lesson plans on cycle I, and $96 \%$ in cycle II, 79.65 on the teacher aspect in cycle I, $95.8 \%$ in cycle II, and on the students aspect $76.6 \%$ in cycle I and $84.7 \%$ on cycle II. It can be said that the use of children's songs as media can improve students' learning outcomes in science at SDN 43 Sungai Sapih Padang.
\end{abstract}

Keywords: Learning Outcomes, Learning Science, Children's Songs

\section{PENDAHULUAN}

Perjalanan lagu anak pada zaman globalisasi tidak begitu diminati karena perkembangan lagu-lagu yang bernuansa dewasa menutupi laju dari lagu anak itu sendiri, sehingga generasi pada saat ini lebih mengenal lagu bernuansa dewasa 
ketimbang lagu anak-anak yang sesuai dengan tingkat perkembangannya. Masa kanakkanak adalah masa yang harus diperhatikan didalam pembentukan karakter, pembentukan itu diawali dibangku Sekolah Dasar utamanya. Kurniawan, (2015) menyatakan perlunya kerjasama antara lingkungan sekolah dan lingkungan keluarga didalam pembentukan karakter anak, pendidikan dalam sekolah dan masyarakat dapat membentuk karakter anak yang berkarakter. Dalam Perpres No 87 Tahun 2017 tentang penguatan pendidikan karakter yang dimana tanggung jawab sekolah untuk memperkuat karakter anak melalui harmonisasi olah hati, olah pikiran dengan pelibatan keluarga.

Pendidikan karakter diperlukan karena pendidikan tidak hanya membuat siswa cerdas, tetapi juga harus berkarakter dan sopan. Pendidikan karakter yang paling sederhana adalah pada saat para siswa masih duduk di bangku Sekolah Dasar, inilah mengapa pemerintah memprioritaskan pendidikan karakter di Sekolah Dasar. Menurut Ramdhani, (2014) karakter diartikan sebagai cara berpikir dan perilaku unik setiap orang dalam keluarga, dan masyarakat, seorang yang berkarakter baik adalah seseorang yang dapat mengambil keputusan dan siap untuk bertanggung jawab atas segala akibat dari keputusanya.

Peran guru didalam pembentukan karakter siswa Sekolah Dasar bisa dilihat dari proses pembelajaran yang dikembangkan, seorang guru diharuskan untuk kreatif mengelolah pembelajaran terutama didalam pembelajaran IPA. Pembelajaran sains Sekolah Dasar terkenal dengan Ilmu Pengathuan Alam (IPA), yang masih merupakan konsep terintegrasi karena tidak dapat dipisahkan dalam bidang kimia, biologi dan fisika (Prananda, 2019). Pembelajaran IPA di Sekolah Dasar bertujuan untuk menanamkan konsep-konsep dasar pembelajaran IPA guna memecahkan masalah nantinya. Pembelajaran IPA harus dilaksanakan melalui inkuiri ilmiah serta kemampuan berkomunikasi sebagai aspek yang penting dari kecakapan hidup.

Mengajar pembelajaran IPA untuk siswa Sakolah Dasar berbeda dengan mengajarkan kepada siswa SMP, SMA, siwa Sekolah Dasar memiliki keunikan dan karakteristik tersendiri. Guru dituntut untuk kreatif didalam mengajar, misalkan didalam memberikan materi harus memiliki strategi pembelajaran yang inovatif agar siswa tidak bosan dengan materi yang diajarkan. Diantara strategi yang menyenangkan untuk siswa SD adalah menggunakan lagu. Lagu adalah sumber bahasa yang sebenarnya, hampir tidak ada batasan waktu untuk menggunakannya yang artinya siswa dapat menggunakan 
lagu sebagai input kapanpun, baik di kelas maupun dirumah, mereka bisa memilih lagu sesuka hati yang disesuaikan dengan pelajaran dan bisa dinyanyikan kapanpun dan dimanapun, maka secara alami akan segera menghubungkan dengan materi pembelajaran IPA. Anggraeni, (2016) mengemukakan lagu anak menceritakan pengalaman anak, emosi anak, keingan dan imajinasi anak, sehingga dapat membantu mengembangkan imajinasi dan penggunaan kata-kata yang sederhana didalam setiap liriknya. Lagu anak dipilih karena bahasanya yang sederhana dan iramanya yang gembira cocok untuk siswa Sekolah Dasar yang konteks belajarnya bermain sambil belajar.

Hasil belajar adalah bagian terpenting dari pembelajaran, karena itu perlu adanya pemahaman tentang kemampuan siswa, dan memahami tingkat pengelaman belajar siswa. Menurut Elly, (2016) hasil belajar merupakan umpan balik dalam proses pembelajaran yaitu tolak ukur yang digunakan untuk mengetahui apakah siswa memahami pembelajaran yang telah dipelajarinya. Jika guru dan siswa dapat berperan aktif dalam proses pembelajaran, maka pelaksanaan IPA akan berjalan dengan baik, selain itu guru harus dapat mengambangkan kemampuan siswa secara efektif, menarik siswa secara aktif, dan melatih siswa untuk meningkatkan kemampuan berpikir dan mengungkapkan pendapat.

Penelitian ini dilakukan berdasarkan observasi peneliti pada kelas V di SDN 43 Sungai Sapih Padang 2019. Beberapa permasalahan yang ditemukan selama proses pembelajaran IPA yaitu, dilihat dari aspek Rencana Pelaksanaan Pembelajaran (RPP) adalah (1) Tujuan pembelajaran RPP lebih kecil dari pada indikator, tujuan pembelajaran Objek, Perilaku, Kondisi, dan Derajat (ABC) tidak mucul, misalnya Kondisi (C) dan Derajat (D) tidak muncul, (2) Rencana kurikulum yang dilihat peneliti selama proses observasi juga belum dilengkapi dengan alat evaluasi, berupa bentuk evaluasi kognitif, emosional, dan psikomotori siswa. (3) RPP yang digunakan guru tidak menggunakan media pembelajaran, termasuk media pembelajaran yang konkret dan menarik.

Sedangkan aspek yang dilihat dari siswa sebagai berikut: (1) Guru tidak melibatkan siswa untuk berpartisipasi dalam pembelajaran, seperti membiarkan siswa berpikir dan tidak meminta siswa mengutarakan pendapatnya selama proses pembelajaran, (2) siswa merasa bosan didalam mengikuti proses belajar, dilihat dari 
banyaknya siswa yang keluar masuk dan ribut dalam kelas.

Dampak dari permasalahan diatas adalah hasil belajar siswa tidak memenuhi standar integritas minimal KKM 75. Dari 22 siswa hanya 7 siswa atau 31,8\% yang memenuhi standar ketuntasan minimal yang ditetapkan di SDN 43 Sungai Sapih Padang, dan 15 siswa di bawah KKM, terhitung 68,2\%. Hal ini menunjukan bahwa pembelajaran tersebut tidak berhasil, apabila masalah ini tidak dapat segara diatasi akan berdampak negatif pada keberhasilan siswa selanjutnya.

Penelitian ini bertujuan untuk mendeskripsikan Peningkatkan hasil belajar menggunakan media lagu anak dalam pembelajaran IPA Sekolah Dasar, penelitian ini dilakukan agar guru dapat meningkatkan hasil belajar siswa pada mata pelajar IPA dengan menggunakan medi lagu anak.

\section{METODE PENELITIAN}

SDN 43 Sungai Sapih Padang adalah sekolah yang peneliti pilih untuk melakukan penelitian. Alasan peneliti memilih lokasi ini berdasarkan pertimbangan sebagai beriku: 1) lokasi yang mudah dijangkau; 2) berdasarkan observasi bahwa guru belum pernah menggunakan media lagu anak; 3) sekolah bersedia menerima inovasi pendidikan, khususnya dalam proses pembelajaran; 4) sekolah menggunakan kurikulum tingkat satuan pendidikan; 5) hasil belajar siswa kelas V pada mata pelajaran IPA masih tergolong rendah.

Subjek penelitian ini adalah guru kelas V SDN 43 Sungai Sapih Padang yang berjumlah 22 siswa 10 siswa laki-laki dan 12 siswa perempuan. Penelitian ini terdari 2 siklus, pada siklus I pertemuan I diterapkan pada tanggal 27 Maret 2019, pertemuan II siklus I dilaksanakan pada tanggal 10 April 2019, siklus II diterapkan pada tanggal 17 April 2019.

Jenis penelitian ini adalah Penelitian Tindakan Kelas (PTK) dengan menggunakan metode kualitatif dan kuantitatif. Penelitian ini dilakukan pada pembelajaran IPA dengan menggunakan model siklus Hopkins yang dikemukakan oleh Arikunto. Proses Penelitian (PTK) merupakan suatu siklus yang dimulai dari perencanaan, pelaksanaan tindakan, observasi dan evaluasi proses, pengambilan hasil tindakan dan refleksi, hingga perbaikan yang diharapkan dapat dicapai (Arikunto, 2012). Sumber data dalam penelitian ini adalah proses pembelajaran IPA kelas V SDN 
43 Sungai Sapih Padang dengan menerapkan media lagu anak yang meliputi perencanaan, pelaksanaan, evaluasi kegiatan, dan perilaku guru, siswa selama proses pembelajaran.

Teknik pengumpulan data yang digunakan adalah observasi dan tes. Pengamatan dilakukan utuuk mengamati latar belakang pembelajaran IPA dan pembelajaran dalam menggunakan media lagu anak dengan berpatokan pada lembar observasi dan peneliti mengkaji apa yang terjadi selama proses pembelajaran. Peneliti juga menggunakan teknik pengujian antara lain tes tertulis dan non tes. Teknik observasi menggunakan instrumen penelitian yang meliputi tabel observasi pelaksanaan pembelajaran pada pihak guru, dan tabel observasi pelaksanaan pembelajaran pada siswa. Hasil tes tertulis dapat menentukan hasil belajar siswa dari aspek kognitif. Lembaran non ujian dirancang untuk untuk melihat perubahan sikap siswa setelah diberi tindakan pembelajaran IPA dengan menggunakan media lagu anak.

Analisis data yang diperoleh dengan menggunakan analisis data kualitatif dan kuantitatif. Pendekatan kualitatif adalah peneliltian yang menghasilkan data deskripsi tentang tuturan, perkataan, dan bentuk perilaku yang diamati dari orang atau sumber informasi. Sebagai mana yang dikemukakan oleh Bogdan, Robert (1992) metode kualitatif merupakan salah satu prosedur penelitian yang menghasilkan data deskriptif berupa kata-kata atau tulisan dan mendeskripsikan perilaku orang yang diamati. Sedangkan penelitian kuantitatif adalah metode dimana rekomendasi penelitian, proses, hipotesis, penelitian, analisa dan kesimpulan data, hingga penggunaan metrik, perhitungan, rumus dan aspek deterministik data numerik ditulis (Musianto, 2014).

Analisis data dilakukan secara terpisah. Tujuanya adalah untuk menemukan informasi spesifik dan terkonsentrasi yang mendukung pembelajaran dan menghambat pembelajaran. Oleh karena itu, dimungkinkan untuk mengembangkan dan memperbaiki berbagai cacat secara akurat dalam aspek terkait.

\section{HASIL DAN PEMBAHASAN}

Pada siklus I dan siklus II penyusunan rencana tindakan pembelajaran IPA berpedoman pada kurikulum pendidikan tahun 2006 dalam bentuk rencana pelaksanaan pembelajaran, peneliti juga menyiapkan media lagu anak, formulir penilaian hasil 
belajar (Kognitif, Akfektif, Psikomotorik), formulis observasi (RPP, aktivitas guru, aktivitas siswa), serta alat dan bahan yang dibutuhkan dalam proses pembelajaran RPP disusunan berdasarkan program semester. Saat melakukan penelitian tindakan, peneliti bertindak sebagai guru (praktisi), dan guru kelas $\mathrm{V}$ bertindak sebagai pengamat.

Rencana pelaksanaan pembelajaran yang akan dilaksanakan meliputi standar kompetensi, kemampuan dasar, indikator, tujuan pembelajaran, materi pembelajaran, metode dan model pembelajaran, media dan sumber pembelajaran, kegiatan dan penilaian pembelajaran. Pada siklus I memfokuskan pada materi; (1) fungsi organ manusia; (2) organ pernafasan manusia dan hewan; (3) organ pencernaan manusia; (4) organ sirkulasi darah manusia. Aspek evaluasi dalam RPP meliputi 7 hal: (1) rumusan tujuan pembelajaran yang jelas; (2) pemilihan bahan ajar; (3) pengaturan bahan ajar; (4) pemilihan sumber, media lagu anak; (5) penyusunan langkah-langkah pembelajaran; (6) keterampilan belajar; (7) integritas instrumen. Berdasarkan pengamatan oleh observer.

Hasil belajar pada pertemuan I meliputi penilaian kognitif, Afektif dan psikomotorik, hasil penilaian dapat dilihat pada diagram batang dibawah ini:

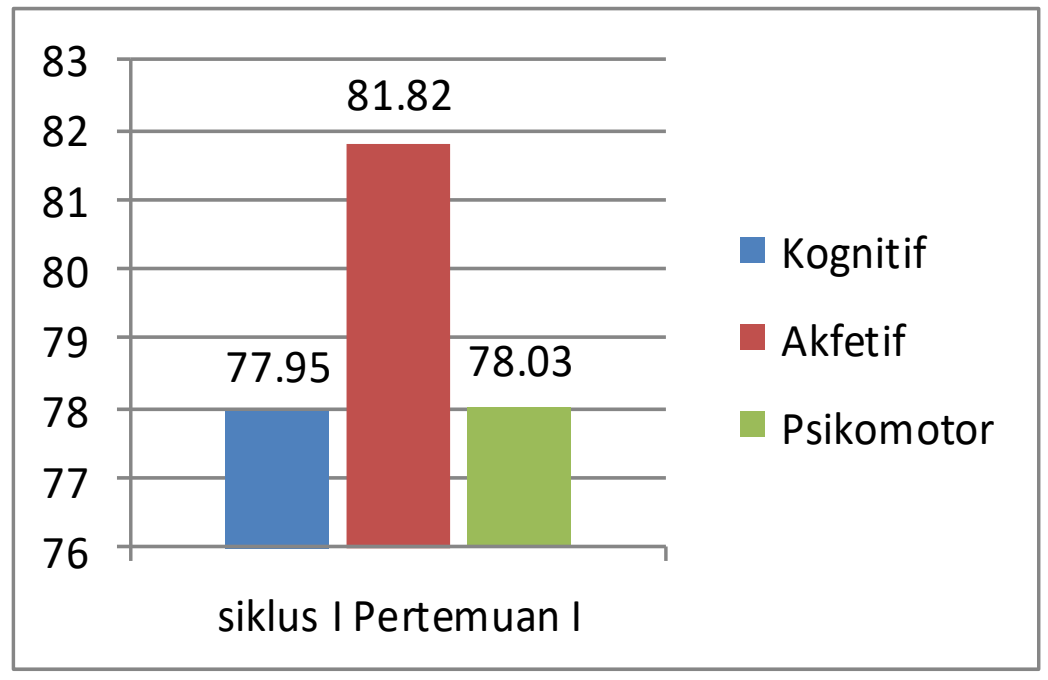

Rata-rata penilaian kognitif siklus I pertemuan I adalah 60,90, selain itu, ratarata hasil evaluasi akfektif siswa pada siklus I adalah 74,53. Pada penilaian psikomotorik siswa adalah 72,72, sehingga rata ketiga aspek tersebut adalah 69,50. Hasil tersebut dibawah KKM yang telah ditetapkan disekolah yaitu 75, untuk itu pembelajaran dilanjutkan pada pertemuan berikutnya. 
Hasil belajar pada siklus I pertemuan II aspek kognitif, afektif dan psikomotor, hasil penilaian tersebut dapat diamati pada diagram dibawah ini:

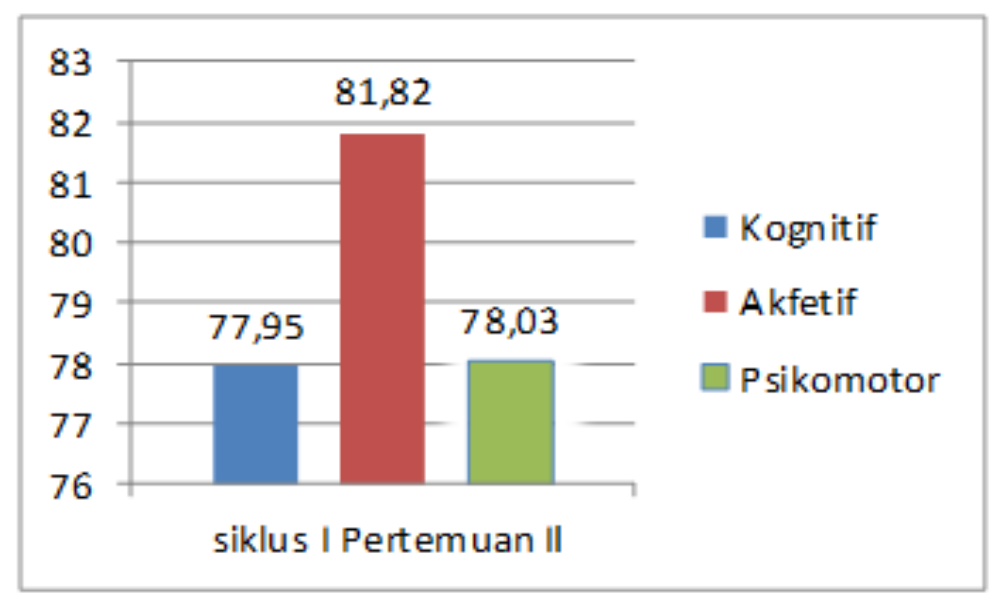

\section{Gambar 2. Diagram Hasil Belajar Siklus I Pertemuan II}

Hasil belajar siklus I pertemuan II meliputi penilaian kognitif, afektif dan psikomotorik, rata-rata hasil evaluasi kognitif adalah 77,95 dan rata-rata hasil evaluasi afektif adalah 81,82 selain itu, hasil rata-rata psikomotor siswa adalah 78,03. Nilai ratarata dari ketiga aspek tersebut adalah 78,52, ini lebih tinggi dari KKM yang ditetapkan adalah 75. Melalui analisis data observasi hasil belajar siswa pada siklus II diperoleh kesimpulan bahwa nilai rata-rata kognitif, akfektif dan psikomotorik dapat dilihat pada diagram dibawah ini:

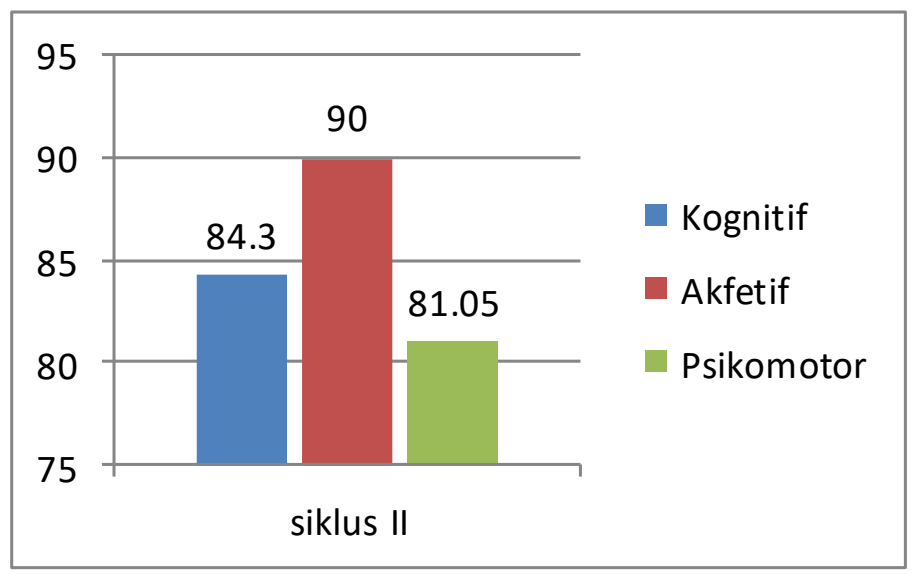

Gambar 3. Diagram hasil belajar Siklus II 
Nilai rata-rata pada aspek kognitif pada diagram diatas adalah 84,30 dan pada aspek afektif adalah 90 sedangkan pada aspek psikomotor dengan rata 81,05. Pada ratarata jumlah siswa yang diperoleh adalah 84,7, dimana 22 siswa diantaranya telah tuntas rasio ketuntasan $100 \%$. Hal ini menunjukan bahwa perbaikan yang dilakukan pada siklus II telah berhasil dilakukan.

Berdasarkan data yang ada di atas dapat disimpulkan bahwa dalam kondisi yang telah ditentukan proses pembelajaran siswa dalam pembelajaran IPA dengan menggunakan media lagu anak pada kelas V SDN 43 Sungai Sapih Padang telah mencapai standar yang telah ditetapkan yaitu tingkat integritas siswa melebihi $75 \%$. Tingkat ketuntasan yang diharapkan didasarkan pada pendapat Kunandar, (2011) yang menyatakan standar ketuntasan ideal untuk setiap indikator adalah 75\%. Artinya penelitian akan berhenti pada siklus II dan tidak dilanjukan pada siklus berikutnya.

Dilihat hasil penelitian dan analisis siklus II, meningkatkan hasil belajar menggunakan media lagu anak dalam pembelajaran IPA di Sekolah Dasar telah dilaksanakan sesuai dengan yang diharapkan, maka siklus II telah berjalan dengan lancar, peneliti telah berhasil menerapkan media lagu anak di kelas V SDN 43 Sungai Sapih Padang, siklus tidak dilanjutkan.

\section{PEMBAHASAN}

Hasil penelitian tentang pelaksanaan pembelajaran IPA menggunakan media lagu anak kelas V SDN 43 Sungai Sapih Padang menunjukan bahwa guru membuat perencanaan dengan menyusun RPP terlebih dahulu. Rusman, (2011) berpendapat bahwa Rencana Pelaksanaan Pembelajaran (RPP) diuraikan dalam silabus untuk memandu kegiatan belajar siswa dalam mencapai kemampuan dasar dan mempersiapkan satu pertemuan atau lebih.

RPP adalah sistem komponen yang saling berhubungan, komponen RPP meliputi identitas sekolah, alokasi waktu, kompetensi inti, kompetensi dasar dan indikator pencapaian kemampuan, tujuan pembelajaran, materi pembelajaran, metode pembelajaran, media pembelajaran, sumber belajar, langkah-langkah pembelajaran dan evaluasi.

Berdasarkan pengamatan terhadap evaluasi RPP siklus I, ditemukan beberapa kekurangan, antara lain: 1) pemilihan bahan ajar yang digunakan guru tidak sesuai 
dengan karakteristik siswa (dan peran siswa), hal ini membuat siswa kesulitan memahami materi; 2) pengorganisasian bahan ajar, ruang lingkup bahan ajar yang belum maksimal, karena bahan ajar yang diberikan guru masih sangat sempit, hal ini mengakibatkan siswa tidak mampu memahami materi dengan baik; 3) penataan bahan ajar tidak memenuhi alokasi waktu yang tercantum dalam RPP karena penyampain bahan ajar tidak memenuhi alokasi waktu yang dijadwalkan sehingga mengurangi waktu istirahat siswa; 4) pemilihan sumber media pembelajaran tidak sesuai dengan karakteristik siswa, sehingga berdampak kebosanan bagi sisiwa; 5) kejelasan proses pembelajaran, langah-langkah pembelajaran yang dilakukan tidak memenuhi alokasi waktu, karena guru tidak bergantung pada waktu yang dijadwalkan, hal ini menyebabkan proses pembelajaran menjadi lama; 6) keterampilan belajar belum sesuai dengan lingkungan siswa; 7) integritas instrumen, pertanyaan tidak mencangkup kriteria penilaian lengkap. Pada siklus II rencana pembelajaran tidak jauh berbeda dengan rencana pembelajaran pada siklus II, tetapi rencana pembelajaran siklus II sangat berhasil.

Proses pembelajaran IPA dari kegitan awal hingga wakhir disesuaikan dengan berpatokan kepada kurikulum KTSP. Sementara siklus II selama pelaksanaan pembelajaran ditemukan beberapa hal sebagai berikut: 1) penyajian materi dengan menggunakan media lagu anak sudah sesuai dengan perencanaan awa; 2) siswa terlihat lebih bersemangat dan paham didalam pembelajaran, karena menggunakan media lagu anak dalam proses pembelajaran; 3) bimbingan guru untuk siswa aktif dan berpartisipasi dalam kegiatan kelas dan mengungkapkan pendapat.

Berdasarkan catatan pada tabel observasi dan hasil diskusi antara peneliti dan pengamat, alasan belum tercapainya hasil belajar yang maksimal pada siklus II adalah masih banyaknya siswa yang belajar secara pasif, suasana belajar yang kurang menyenangkan, kurangnya motivasi guru. Berdasarkan analisis data penelitian siklus II, hasil belajar IPA dan media lagu anak sudah mencapai nilai yang diharapkan. Oleh karena dilihat dari hasil yang diperoleh pada siklus II, pelaksanaan siklus II sudah baik, dan peneliti sudah mencapai nilai yang diharapkan. Berhasil meningkatkan hasil belajar siswa dengan menggunakan media lagu anak dalam pembelajaran IPA di kelas V SDN 43 Sungai Sapih Padang. 


\section{KESIMPULAN}

Kesimpulan yang dapat diambil dari penelitian ini adalah; 1) rencana pembelajaran dengan media lagu anak telah dilakukan sesuai dengan rencana yang telah ditetapkan, yang dilaksanakan dalam 2 siklus. Ada II pertemuan dalam siklus I dan I pertemuan pada siklus II. Hasil observasi rencana hasil siklus I 87,5\% dan hasil siklus II $96 \%$.

Pelaksanaan pembelajaran dengan menggunakan media lagu anak dilihat dari dua aspek yaitu guru dan siswa. Pengamatan dari aspek guru dalam proses pengajaran telah sesuai dengan KTSP, dari putaran I hingga putaran ke II persentase belajar siswa terus meningkat. Persentase aktivitas guru 79,65 pada siklus I dan 95,8\% pada siklus II. Dilihat dari aspek siswa, kemudian aspek sisiwa juga meningkat dari siklus I ke siklus II persentase skor yang diperoleh adalah 76,6\% hingga 96,1\%, hasil penelitian menunjukan bahwa dari siklus I ke siklus II proses pembelajaran siswa kelas V SDN 43 Sungai Sapih Padang mengalami peningkatan, yaitu siklus I rata-rata perolehan siswa hanya $74,00 \%$ meningkat menjadi $84,71 \%$.

\section{DAFTAR PUSTAKA}

Anggraeni, S. W. (2016). Penggunaan Media Lagu Anak Dalam Meningkatkan Hasil Pembelajaran Menulis Puisi. Jurnal Sekolah Dasar, 1(1), 49-60. https://doi.org/10.36805/jurnalsekolahdasar.v1i1.62

Arikunto, S. (2012). Penelitian Tindakan Kelas. Jakarta: Bumi Aksara.

Bogdan, R. dan T. (1992). Pengantar Metode Penelitian Kualitatif, Terjemahan oleh Arief Rurchan. Surabaya : Usaha Nasional.

Elly, R. (2016). Hubungan Kedsiplinan Terhadap Hasil Belajar Siswa Kelas V Di Sd Negeri 10 Banda Aceh. Jurnal Pesona Dasar, 3(4), 43-53.

Hasan, H. (2018). Keterampilan Mengajar Bahasa Arab Materi Istima Menggunakan Media Lagu. Al Qalam: Jurnal Ilmiah Keagamaan Dan Kemasyarakatan, 15(28), 127. https://doi.org/10.35931/aq.v0i0.7

Kristin, F. (2016). Analisis Model Pembelajaran Discovery Learning dalam Meningkatkan Hasil Belajar Siswa SD. Jurnal Pendidikan Dasar PerKhasa, 2(1), 90-98. 
http://jurnal.stkippersada.ac.id/jurnal/index.php/JPDP/article/view/25\%0ADisco very Learning, Learning Outcomes

Kunandar. (2011). Guru profesional implementasi kurikulum satuan pendidikan (KTSP) dan sukses dalam sertifikasi Guru (p. 2010). PT. Raja Grafindo Persada: Jakarta.

Kurniawan, M. I. (2015). Tri Pusat Pendidikan Sebagai Sarana Pendidikan Karakter Anak Sekolah Dasar. PEDAGOGIA: Jurnal Pendidikan, 4(1), 41. https://doi.org/10.21070/pedagogia.v4i1.71

Miranti, I., Engliana, \& Hapsari, F. S. (2015). Penggunaan Media Lagu Anak-Anak Dalam Mengembangkan Kemampuan Kosakata Bahasa Inggris Siswa Di PAUD. Jurnal Ilmiah Kependidikan, II(No. 2 Juli), 167-173.

Musianto, L. S. (2014). Perbedaan Pendekatan Kuantitatif Dengan Pendekatan Kualitatif Dalam Metode Penelitian. Journal Manajmen Dan Kewirausahaan, 4(2), 123-136. https://doi.org/10.9744/jmk.4.2.pp.123-136

Nupita, E. (2013). Penerapan Model Pembelajaran Penemuan Terbimbing untuk Meningkatkan Hasil Belajar dan Keterampilan Pemecahan Masalah IPA pada Siswa Kelas V Sekolah Dasar. Journal Education, 1(2), 1-9.

Prananda, G., \& Hadiyanto. (2019). Korelasi Antara Motivasi Belajar Dengan Hasil Belajar Siswa Dalam Pembelajaran IPA Di Sekolah Dasar. Jurnal Basicedu, 3(3), 524-532.

Ramdhani, M. A. (2014). Wage Policy and Wage Determination in 1983. Jurnal Pendidikan UNIGA, 8(1), 28-36. https://doi.org/10.1177/002218568402600108

Roffiq, A., Qiram, I., \& Rubiono, G. (2017). Media Musik Dan Lagu Pada Proses Pembelajaran. JPDI (Jurnal Pendidikan Dasar Indonesia), 2(2), 35. https://doi.org/10.26737/jpdi.v2i2.330

Rusman. (2011). Model-model Pembelajaran. Jakarta: Rajawali Press.

Widiana, I. W. (2016). Pengembangan Asesmen Proyek Dalam Pembelajaran Ipa Di Sekolah Dasar. JPI (Jurnal Pendidikan Indonesia), 5(2), 147. https://doi.org/10.23887/jpi-undiksha.v5i2.8154 